\title{
PENINGKATAN EKONOMI MASYARAKAT DESA TELUN KENAS MELALUI OPTIMISASI MANAJEMEN USAHA TERNAK KELOMPOK
}

\author{
Prihatin Lumbanraja ${ }^{1)}$, Arlina Nurbaity Lubis ${ }^{2)}$, Hasan Sakti Siregar ${ }^{3)}$ \\ 1)Fakultas Ekonomi dan Bisnis Universitas Sumatera Utara \\ Email: titinlumbanraja@yahoo.com \\ 2)Fakultas Ekonomi dan Bisnis Universitas Sumatera Utara \\ Email: arlinalubis10@gmail.com \\ ${ }^{3)}$ Fakultas Ekonomi dan Bisnis Universitas Sumatera Utara \\ Email: hasan@usu.ac.id
}

\begin{abstract}
Abstrak
Potensi usaha desa sangat jarang dimanfaatkan secara maksimal untuk kemakmuran dan kemajuan ekonomi dari masyarakat desa. Umumnya potensi tersebut dimanfaatkan oleh perusahaan besar yang mempekerjakan masyarakat setempat. Langkah ini belum efektif dalam mendorong ekonomi masyarakat desa. Secara keahlian, masyarakat setempat sudah memiliki kemampuan yang diperlukan untuk mengembangkan secara mandiri potensi desa yang ada. Kegiatan pengabdian membuat dua kelompok kecil yang menjalankan usaha ternak berkelanjutan dan hingga saat ini berkembang menjadi tiga kelompok. Tim pengabdian telah memberikan bantuan induk ternak dan kandang untuk masing-masing kelompok mitra. Tim pengabdian akan membagikan ilmu seputar bagaimana melakukan usaha yang berkelanjutan, menciptakan komitmen dalam kelompok, semangat berwirausaha dan saling membantu masyarakat, serta bagaimana menentukan harga jual yang sesuai untuk ternak kelompok serta memberikan buku seputar budidaya ternak. Selanjutnya tim pengabdian akan melakukan monitoring dan evaluasi secara berkala sekaligus memberikan pendampingan dalam prakteknya. Diharapkan kegiatan ini akan semakin membantu masyarakat memperoleh modal yang diperlukan dalam beternak secara mandiri untuk membantu ekonominya sekaligus semangat dalam warga lain yang memerlukan transfer pengetahuan.
\end{abstract}

Kata Kunci: Usaha Berkelanjutan, Manajemen Organisasi, Kewirausahaan, Manajemen Keuangan, Semangat Gotong-Royong, Usaha Ternak

\section{PENDAHULUAN}

Sektor ekonomi rakyat merupakan sektor yang memegang peranan penting dalam pemerataan kesejahteraan rakyat hingga ke seluruh wilayah Indonesia. Undang-Undang Dasar Republik Indonesia Tahun 1945, serta ditegaskan kembali dalam Sila kelima Pancasila, menyatakan sikap dalam membangun keadilan sosial bagi seluruh rakyat Indonesia. Butir pengamalan sila tersebut menyatakan sikap tolong-menolong serta membangun kemajuan dan kesejahteraan bersama dalam mencapai masyarakat Indonesia yang makmur (Kemenristek Dikti, 2016).

Sektor ekonomi rakyat sulit berkembang, khususnya bagi masyarakat di wilayah pedesaan. Pola berpikir masyarakat Indonesia pada umumnya masih memiliki mental pekerja daripada mental wirausaha. Partisipasi angkatan kerja akan membantu pergerakan roda pembangunan dengan mengurangi tingkat pengangguran. Akan tetapi, efek pengganda dari memulai usaha baru lebih besar daripada sekedar menjadi angkatan kerja. Setiap satu lapangan usaha yang baru tumbuh akan memerlukan tenaga kerja yang meningkatkan ketersediaan lapangan kerja pada wilayah tersebut. Jumlah lapangan pekerjaan yang dapat dihasilkan dari satu usaha akan terus berkembang seiring dengan perkembangan usaha tersebut. Dalam hal ini, wirausaha menjadi kunci penting dalam percepatan pembangunan Indonesia. Revolusi mental masyarakat adalah kunci kesejahteraan 
dalam ekonomi global (Merrill dan Burrolla, 2015).

Kegiatan Tridharma Perguruan Tinggi terdiri dari kegiatan Pendidikan, Penelitian, dan Pengabdian Kepada Masyarakat. Dosen-dosen Universitas Sumatera Utara (USU) tidak hanya dituntut mengabdi dalam bentuk kegiatan pengajaran dan penelitian saja, melainkan juga mengaplikasikan keilmuannya untuk kemajuan masyarakat. Rencana pengabdian pada masyarakat yang diajukan dalam kesempatan ini bertujuan untuk membangun kewirausahaan bagi masyarakat pedesaan melalui pengembangan kelompok dan pemberdayaan kelompok. Tujuan utama dari kegiatan pengabdian tersebut adalah memberdayakan serta mengoptimalkan potensi masyarakat untuk menjadi masyarakat yang lebih sejahtera, mampu berkembang, serta saling tolong-menolong dalam kehidupan sehari-hari sesuai dengan butir pengamalan pancasila.

Desa Talun kenas terletak di Kecematan Deli Serdang yang memiliki potensi pengembangan ternak yang tinggi. Wilayah pedesaan tersebut memiliki rerumputan yang luas serta mudah ditemukan di alam liar. Pangan ternak khususnya herbivora mudah ditemukan di wilayah tersebut. Lahan yang luas serta potensi hijauan pakan dan sinergi dengan limbah pertanian menjadi kunci dalam mendongkrak potensi ternak di wilayah tersebut (Rohaeni, 2014).

Desa Talun kenas sudah memiliki dua peternakan besar, PT ANEKA TERNAK FARM yang mengembangkan usaha berbagai ternak dan PT LEONG yang mengembangkan usaha ternak ayam. Masyarakat setempat banyak yang bekerja sebagai peternak pada dua perusahaan tersebut. Masyarakat setempat sudah memiliki keahlian yang diperlukan untuk mengembangkan ternak secara mandiri.

Desa Talun kenas pernah memperoleh bantuan permodalan untuk usaha ternak dari pemerintah Deli Serdang pada tahun 2015.
Akan tetapi, program tersebut tidak berhasil dikembangkan dengan baik karena hanya fokus pada pemberian bantuan permodalan saja. Ternak yang berkembang ke tangan masyarakat terhenti karena kebutuhan ekonomi masyarakat. Pengelolaan yang terjadi dalam keorganisasian kelompok yang dibantu sebelumnya belum optimal, terlebih rendahnya pengawasan dan kurangnya kegiatan pendampingan pada program pemerintah sebelumnya.

Masyarakat setempat sudah memiliki kesesuaian dengan pengembangan usaha ternak dan sangat meminati pengembangan usaha tersebut. Mitra pengabdian pada masyarakat yang diajukan dalam program ini sebelumnya telah bekerja pada perusahaan ternak serta berhasil mengembangkan ternak pada program sebelumnya dengan baik. Pengembangan kelompok ternak yang diajukan dalam kegiatan ini didasarkan pada dua mitra yang berhasil dan tetap mempertahankan ternaknya dari program pemerintah sebelumnya.

\section{MASALAH}

Mitra saat ini memiliki keterbatasan modal usaha dalam membangun kelompok serta mengembangkan sikap saling tolongmenolong dalam mengembangkan ekonomi masyarakat setempat. Mitra sangat memerlukan pendampingan untuk kelompok ternak yang baru dibentuk agar kelompok tersebut dapat berkembang dan dapat berkomitmen dalam mencapai tujuan mereka, yaitu meningkatkan ekonomi masyarakat sembari mengoptimalkan potensi yang dimiliki Desa Telun Kenan. Revolusi mental kelompok sangat diperlukan dalam menyelesaikan permasalahan.

Masyarakat setempat belum memiliki kemampuan manajemen yang baik, mulai dari proses perencanaan hingga pengendalian kegiatan dalam budidaya ternak yang berkelanjutan. Terputusnya budidaya pada program sebelumnya sangat dimungkinkan karena kesalahan manajemen 
pengelolaan budidaya ternak yang dilakukan. Masyarakat juga menentukan harga jual ternak yang dikembangkannya hanya berdasarkan kebutuhan mendesak yang mereka alami. Nilai jual dari ternak yang diberikan tidak optimal bagi peternak

\subsection{Solusi yang Ditawarkan}

Tujuan dari kegiatan pengabdian pada masyarakat yang diajukan dalam proposal ini adalah pemberdayaan masyarakat melalui pengoptimalan potensi yang dimiliki desa serta membangun semangat pancasila untuk saling menolong antar masyarakat. Kegiatan mendasar yang perlu dilakukan dalam pengabdian ini adalah pengembangan kelompok dengan kelompok inti peternak yang memiliki keahlian dalam membudidayakan ternak dengan baik. Pengembangan kelompok didasarkan dengan memberikan bantuan berupa hewan ternak yang akan menjadi modal awal pengembangan peternakan kelompok serta pengadaan kandang ternak untuk mendukung kegiatan pada kelompok tersebut. Kegiatan kelompok berdasarkan kegiatan gotong-royong dan tidak mengharuskan mitra dan anggotanya dalam waktu penuh mengelola peternakan, melainkan saling bergantian sehingga tidak mengganggu aktivitas utama mitra dan kelompoknya.

Tim pengabdian akan memberikan penyuluhan berupa edukasi kepada mitra terkait dengan isu-isu manajemen, khususnya dalam pengelolaan usaha berkelanjutan. Tim pengabdian juga akan memberikan penyuluhan untuk membangkitkan semangat kewirausahaan kelompok mitra, edukasi pengembangan dan komitmen berorganisasi, serta manajemen keuangan, khususnya dalam menentukan nilai jual ternak yang diberdayakan.

Tim pengabdian akan
melakukan pendampingan kepada
kelompok mitra serta mengevaluasi
perkembangan yang terjadi secara berkala.
Pendampingan yang dilakukan akan

mendorong semangat mitra bahwa mereka dengan serius diperhatikan oleh pihak pengabdian sekaligus menjadi kontrol dalam mengevaluasi perkembangan kelompok mitra.

\section{METODE PELAKSANAAN}

\subsection{Metode Pendekatan}

Kegiatan pengabdian kepada masyarakat mono tahun yang diusulkan akan dilaksanakan dengan melakukan bantuan permodalan usaha kelompok mitra, melakukan kegiatan penyuluhan, serta pendampingan dan pengawasan kegiatan mitra dan kelompoknya. Dukungan permodalan dana kelompok membantu start-up budidaya ternak di Desa Talun kenas. Penyuluhan bertujuan untuk edukasi pengetahuan dasar manajemen serta keuangan dalam mengelola kelompok dan usaha kelompok. Pendampingan serta pengawasan dilakukan sebagai suplemen serta kendali yang dilakukan agar kegiatan pengabdian tercapai sesuai sasaran yang diharapkan.

\subsection{Tahapan Kegiatan}

Rencana kegiatan-kegiatan yang akan dilakukan dalam upaya penyelesaian permasalahan mitra dilakukan berdasarkan tahapan-tahapan pelaksanaan, yaitu:

1. Pembentukan kelompok dengan pusat ketua kelompok mitra pengabdian yang telah dilaksanakan pada saat survei situasi dan penandatanganan persetujuan mitra

2. Pembuatan kandang ternak bersama mitra yang dibiayai oleh tim pengabdian

3. Pemberian masing-masing 2 ekor kambing betina dan 1 ekor kambing jantan kepada kelompok mitra.

4. Pelaksanaan forum diskusi terbuka antara tim pengabdian, mitra, dan anggota mitra tentang tata cara atau aturan dalam upaya pengembangan ekonomi dan potensi ternak anggota mitra. 
5. Penyuluhan sekaligus pelatihan kepada mitra dalam bidang manajemen operasi usaha, manajemen organisasi, manajemen keuangan, serta kewirausahaan bagi mitra dan kelompoknya

6. Pemberian buku-buku relevan dalam lingkup pengabdian untuk kepustakaan kelompok

7. Pendampingan sekaligus evaluasi secara berkala kepada mitra dan kelompoknya

8. Penilaian kemajuan mitra dan kelompoknya dengan base penilaian kondisi awal sebelum pelaksanaan kegiatan pengabdian.

\section{HASIL DAN LUARAN YANG DICAPAI}

\subsection{Pembentukan dan Pengembangan Kelompok Usaha Ternak Mitra}

Kegiatan pengabdian di Desa Telun Kenas Kecamatan Deli Serdang, Sumatera Utara, dimulai dengan membentuk kelompok usaha ternak sebagai sarana dalam mendorong perekonomian masyarakat setempat melalui budidaya ternak secara mandiri. Banyak dari masyarakat sekitar bekerja sebagai buruh harian di perusahaan-perusahaan usaha ternak, seperti PT Leong. Pengalaman bekerja masyarakat di perusahaan tersebut menjadi modal dasar atau keahlian dasar yang dimiliki masyarakat dalam merawat dan membudidayakan ternak. Desa Telun Kenas memiliki sumber pangan ternak yang sangat banyak dan tumbuh secara liar di area perkampungan, bahkan di pinggiran jalan desa. Potensi usaha budidaya ternak di wilayah tersebut sangat tinggi.

Kegiatan pengabdian membentuk kerja sama dengan dua kelompok mitra yang siap menjadi wadah dalam kegiatan pengabdian. Masing-masing ketua mitra merupakan tokoh yang dikenal baik oleh masyarakat sekitar, yaitu Kepala Desa saat ini dan Mantan Kepala Desa Telun Kenas periode sebelumnya. Pemilihan ketua mitra ditujukan pada potensi ketua dalam mengatur dan mengembangkan kelompok serta menarik kepercayaan masyarakat pada program pengabdian yang dilakukan. Kedua ketua kelompok menyatakan kesiapannya menjadi ketua kelompok mitra per tanggal 14 Mei 2017. Pada minggu pertama Bulan Agustus 2017, masing-masing mitra telah memiliki tiga orang anggota kelompok yang siap mengikuti program yang disiapkan tim pengabdian kepada masyarakat untuk memajukan ekonomi masyarakat Desa Telun Kenas.

Kunjungan tim pengabdian pada Tanggal 9 September 2017 memberikan hasil pengembangan kelompok usaha ternak mitra. Sebelumnya, direncanakan kelompok mitra akan semakin berkembang dengan bertambahnya anggota. Meskipun target tersebut belum tercapai, namun jumlah kelompok usaha ternak mitra berkembang menjadi tiga kelompok mitra. Kelompok ketiga dipimpin oleh Mantan Kepala Desa Telun Kenas dua periode sebelumnya. Kunjungan pada tanggal 9 September ini juga menjadi kunjungan disertai dengan kegiatan penyuluhan dan pelatihan terkait ipteks yang diberikan.

Tim pengabdian melakukan evaluasi perubahan situasi mitra pada tanggal 21 Oktober 2017. Dalam kesempatan tersebut jumlah kelompok mitra tetap tiga kelompok namun dengan jumlah anggota yang semakin besar. Masing-masing kelompok mampu menjaga keakraban dan kesatuan kelompoknya dengan catatan tidak ada anggota kelompok yang keluar dari kelompok mitra meski telah memperoleh peranakan kambing. Tingkat komitmen berorganisasi dari masyarakat terhadap kelompok dan semangat gotong royongnya tinggi.

\subsection{Pembekalan Pengetahuan dan Pembuatan Kandang Ternak Mitra}

Dalam upaya peningkatan pendapatan masyarakat melalui pengembangan usaha ternak kelompok, mitra memerlukan 
kandang ternak yang digunakan untuk keperluan budidaya ternak. Tim pengabdian memberikan buku-buku manajemen usaha ternak yang didalamnya memberikan saran-saran teknis dalam pembuatan kandang ternak yang memaksimalkan potensi budidaya ternak. Mitra dan kelompoknya sudah memiliki pengetahuan dasar tentang budidaya ternak yang dimaksudkan oleh tim pengabdian. Berdasarkan hal tersebut, tim pengabdian melakukan brainstorming dengan mitra yang memadukan antara teknis pembuatan kandang ternak berdasarkan buku dengan pengalaman ketua mitra dalam praktik budidaya ternak.

Brainstroming yang dilakukan mencapai kesepakatan tentang pengadaan kandang ternak untuk rencana budidaya yang akan dilaksanakan sebagai agenda pengabdian dalam meningkatkan pendapatan masyarakat setempat. Kandang dibuat dengan material kayu dan daitur sedemikian sehingga pakan ternak dapat ditempatkan dengan posisi yang mudah digapai oleh ternak dari dalam kandang, serta memberikan luas yang cukup untuk tempat tinggal ternak. Per tanggal 7 September 2017, dua kelompok mitra sudah memiliki kandang yang layak dan dapat digunakan untuk operasi seharihari pengelolaan budidaya ternak. Dua dari tiga kelompok mitra sudah memiliki kandang sendiri yang ditempatkan di halaman rumah ketua kelompok. Tahap selanjutnya dari kegiatan ini adalah pengadaan kandang kelompok untuk mitra ketiga agar tidak lagi antar kelompok saling berbagi lahan pengembangan usaha.

Mitra ketiga dari kegiatan pengabdian pada saat evaluasi tanggal 21 Oktober 2017 dilaksanakan telah berupaya membuat kandang kandang untuk kelompok ternak miliknya. Mitra ketiga diberikan modal indukan kambing oleh mitra lainnya. Mereka saling bantu membantu dalam membangun mitra ketiga. Kandang yang dibuat untuk mitra ketiga adalah hasil gotong royong dengan memanfaatkan kas kelompok yang diberikan sebelumnya. Mahasiswa turut ambil bagian dalam kegaitan ini.

\subsection{Pembekalan Pengetahuan dan Pencapaian Operasi Usaha Ternak}

Secara teknis, mitra dan kelompoknya sudah menguasai dasardasar dalam pengelolaan operasi usaha ternak berdasarkan pengalaman kerja yang dimiliki oleh mitra dan kelompoknya. Kunjungan pengabdian sebelumnya telah mengidentifikasi bahwa salah satu permasalahan dalam pengelolaan usaha ternak adalah keberlangsungan usaha yang tidak berlangsung lama. Pembekalan pengetahuan operasi usaha ternak yang dilakukan berkaitan dengan bagaimana melakukan pengelolaan operasi usaha yang mencapai sustainable growth. Bila usaha itu terhenti, maka pelaku hanya akan memperoleh keuntungan dalam jangka pendek saja, tidak akan mendorong peningkatan pendapatan masyarakat yang merupakan target jangka panjang. Oleh karena itu, penting bagi tim pengabdian untuk menegaskan sustainable growth kepada mitra dan kelompoknya.

Pada pengelolaan usaha masyarakat sebelumnya, ternak dengan mudah dijual ketika mereka memerlukan uang dalam waktu cepat. Masyarakat yang sebelumnya pernah mandiri melakukan budidaya ternak harus berhenti menjalankan usaha ternak karena memerlukan uang untuk keperluan lainnya. Selain itu, bila ternak dinilai 'masuk angin', sudah waktunya ternak dijual tanpa memikirkan keberlangsungan usahanya.

Dalam aspek ini, ketua kelompok dibekali dengan pengetahuan dasar dalam menjaga perkembangan usaha yang berkelanjutan dalam jangka panjang. Mitra dikenalkan dengan fase pertumbuhan usaha dan bagaimana mengidentifikasi langkah yang perlu diterapkan dalam mengendalikan usaha yang berkelanjutan. Mitra dikenalkan dengan tindakan yang dapat dilakukan ketika mendapati usaha sedang tumbuh dan bagaimana mengatur 
keberlangsungan usaha yang mendukung, namun terpisah dari manajemen usaha kelompok.

Mitra dan Kelompoknya diberikan sepuluh ekor ternak dengan rincian enam ekor kambing biri-biri dan empat ekor kambing biasa yang telah dewasa. Kambing yang diberikan tersebut siap dikembangbiakkan dan sesuai dengan tujuan pengabdian. Dalam praktiknya, ternak yang diberikan kepada kelompok dibudidayakan dengan ketentuan bergilir. Anakan ternak yang diperoleh dari hasil pengelolaan ternak dibagi menjadi dua bagian, yaitu untuk anggota (dibagikan secara bergilir) dan untuk perkembangan kelompok. Dalam hal ini, kegiatan ternak akan berkembang, tidak hanya memajukan kelompok, namun mempersiapkan modal bagi masyarakat setempat.

Hasil pengabdian yang dilakukan melahirkan komitmen mitra dalam melaksanakan operasi kegiatan pembagian anakan kambing hasil dari pengelolaan ternak. Indukan yang diberikan kepada mitra dipilih yang sudah mengandung sehingga mitra dapat dievaluasi berdasarkan sikap setelah memperoleh anakan pertama. Anakan pertama disepakati diberikan kepada kelompok dan ketua kelompok. Hasil evaluasi menunjukkan bahwa mitra dan kelompoknya semakin semangat dalam mengelola kepentingan kelompok karena merasa hal ini bermanfaat bagi mereka. Sayangnya, evaluasi peningkatan pendapatan masyarakat yang sifatnya jangka panjang belum dapat dilakukan. Akan tetapi, dari kegiatan ini kita dapat melihat bahwa aset warga terutama dalam usaha ternak mengalami peningkatan yang sangat berpotensi dalam mendorong pendapatan warga di masa yang akan datang.

\subsection{Sosialisasi dan Pencapaian Keilmuan Manajemen Kelompok}

Salah satu target dari kegiatan pengabdian ini adalah memajukan usaha kelompok.
Oleh karena itu, di dalam konteks pengabdian ini, diperlukan pemahaman bagaimana menjaga harmonisasi dan menggerakkan kelompok secara efektif dan efisien. Mitra merupakan ketua kelompok yang bertanggung jawab dalam mengelola kelompoknya. Diharapkan, melalui pengabdian ini mitra dapat memperoleh dukungan pendapatan tambahan bersama kelompoknya. Tujuan pengabdian ini bukan memberdayakan ketua kelompok saja, namun juga memberdayakan seluruh anggota kelompok yang diharapkan akan menyebar ke masyarakat.

Manajemen organisasi dan kelompok sangat penting dalam menjaga harmonisasi dan kesuksesan kelompok. Bila seluruh anggota kelompok dapat menyatu dalam wadah kelompok, mengesampingkan hasrat individu dan mampu fokus dalam mencapai kesuksesan kelompok, menjadikan tujuan kelompok sebagai tujuan pribadi, kelompok tersebut terikat dengan kesuksesan kelompok. Usaha bersama tidak dapat sukses dengan baik bila hanya dikerjakan oleh satu orang saja. Selain itu, kegiatan pengabdian ini juga tidak akan tepat sasaran bilamana tidak terjadi koherensi antar kelompok dalam masing-masing kelompok mitra.

Pada kegiatan pengabdian yang telah dilakukan, mitra dibekali bagaimana mengontrol dan memotivasi anggota kelompok. Mitra juga diberikan pengetahuan bagaimana melakukan manajemen konflik bilamana terjadi selisih paham antar anggota kelompok. Peran mitra dalam pengabdian ini adalah role model bagi anggotanya sekaligus berperan sebagai trainer of trainee untuk masing-masing kelompoknya. Ilmu yang diperoleh dari tim pengabdian diberikan kepada anggota kelompok sembari membimbing kelompok dalam mengembangkan usaha ternak kelompok.

Pada pengabdian yang telah dilaksanakan, terlihat bahwa mitra sudah memiliki bekal penting dalam manajemen 
kelompok. Mitra mengenal baik anggota kelompok masing-masing, serta dihormati oleh anggota kelompoknya. Mitra dipercaya oleh anggota kelompok untuk memimpin pengelolaan usaha ternak kelompok yang dipersiapkan tim pengabdian. Anggota kelompok siap melakukan pembagian tugas dalam upaya mencapai kesuksesan kelompoknya.

Hasil kegiatan pendampingan yang dilakukan kepada mitra mengindikasikan bahwa dalam pelaksanaannya, manajemen kelompok selalu membawa konflik kepentingan. Mitra dan kelompoknya harus menghadapi fokus kepentingan antara kepentingan pribadi dan kepentingan kelompok. Pada awalnya, mitra sukar melakukan manajemen waktu dalam membagi antar kepentingan pribadi dan kepentingan kelompok. Pada umumnya anggota mitra dan ketua juga berkerja sebagai buruh lepas di perusahaan peternakan sekitar sehingga pada saat-saat tertentu waktu antara tugas kelompok dan pekerjaan pribadi bertabrakan. Seiring dengan pembelajaran dan pendampingan yang dilakukan antara tim pengabdian dan mahasiswa kepada kelompok mitra, harmonisasi kelompok tercapai. Kelompok saling mengert kesibukan anggota dan bersikap tegas namun saling membantu agar fokus tugas kelompok tercapai sembari menyeimbangkan kegiatan antara pekerjaan utama dan ternak kelompok.

\subsection{Sosialisasi dan Pencapaian Activity- based Costing dalam Menghitung Biaya}

Survei yang dilakukan tim pada masyarakat Telun Kenas mengindikasikan bahwa penentuan harga jual ternak yang dimiliki oleh masyarakat tidak didasarkan pada perhitungan yang berbasis akuntansi. Hasil ternak dijual berdasarkan kesepakatan harga yang dibentuk oleh penjual dan pembeli. Akan tetapi, masyarakat, dalam hal ini pemilik ternak, tidak memiliki dasar acuan yang jelas dalam menentukan harga jual. Hal ini memberikan potensi kesalahan perhitungan harga jual bagi ternak.

Dalam upaya menyelesaikan potensi masalah mitra dan masyarakat Telun Kenas, tim pengabdian memperkenalkan activity-based costing dalam menentukan harga pokok produksi dan menentukan harga yang layak untuk nilai jual ternak. Mitra diajarkan untuk menghitung hasil keringat mereka ke dalam beban (biaya) dalam menghasilkan ternak. Selama ini, hasil jerih payah mereka, serta pakan yang digunakan untuk merawat ternak tidak dihitung dalam menentukan harga jual. Memang benar bahwa lingkungan setempat tidak sulit menghasilkan pakan ternak, namun usaha mereka mengumpulkan pakan tersebut sudah sepatutnya dihargai.

Mitra diajarkan untuk melakukan pembukuan, pencatatan segala aktivitas yang berhubungan dengan jalannya usaha pengelolaan ternak sebagai dasar acuan perhitungan harga pokok produksi. Setelah harga pokok produksi jelas dihitung, mereka dapat menentukan mark-up keuntungan dari hasil usahanya yang dijadikan sebagai nilai jual yang wajar.

Evaluasi tanggal 21 Oktober 2017 mengindikasikan bahwa kemampuan keuangan mitra masih belum sesuai dengan harapan. Komitmen dalam memisahkan keuangan pribadi dari kepentingan usaha sulit dilakukan. Kebutuhan kelompok terkadang bercampur dengan kebutuhan keluarga dari mitra dan kelompoknya. Dari sisi perhitungan biaya, hanya tiga dari dua belas anggota mitra keseluruhan yang fokus dalam melaksanakan dan menerapkan activity based-costing. Pembelajaran akuntansi pada mitra masih harus diberikan secara perlahan. Perubahan mulai terjadi, dimulai dari peningkatan kemampuan ketua kelompok yang diharapkan kedepannya mampu mempengaruhi perilaku anggota kelompoknya dalam melakukan activity based costing. 
Prihatin. et.al. Peningkatan Ekonomi Masyarakat Desa Telun Kenas Melalui Optimisasi Manajemen Usaha Ternak Kelompok

\begin{tabular}{ll}
\hline 4.6. Sosialisasi dan Pencapaian & \multicolumn{1}{c}{ Hasil pengabdian yang dilakukan } \\
Kewirausahaan Mitra & $\begin{array}{l}\text { mengindikasikan bahwa pengelolaan } \\
\text { keuangan dari mitra perlahan mengalami }\end{array}$ \\
Pengabdian yang telah dilakukan & $\begin{array}{l}\text { peningkatan. Sebelumnya mitra } \\
\text { sepenuhnya mencampurkan antara }\end{array}$ \\
mengidentifikasi bahwa mitra cukup & keuangan untuk usaha, pribadi, dan \\
memiliki semangat kewirausahaan hingga & keluarga. Saat ini, ketua kelompok sudah \\
pada tahapan tertentu. Mitra dengan & mulai melakukan pemisahan keuangan. \\
semangat mempertahankan dan memulai & Mitra mulai berpikir mandiri dan tidak lagi \\
usahanya ketika ada modal. Mitra juga & bergantung pada pemberi kerja. Mitra dan \\
mampu mengelola usaha dengan baik. & kelompoknya bersemangat untuk \\
Akan tetapi, ketika mitra dihadapkan & mengembangkan usaha ini dan \\
dengan masah keuangan, terutama & menjadikan diri mereka sebagai \\
desakan dari keperluan rumah tangga, & pengusaha ternak mandiri.
\end{tabular}
Mitra tidak ragu memutus usahanya dan kembali bekerja sebagai karyawan. Mental kewirausahaan mitra masih bercampur dengan mental pekerja dari mitra. Hasil dari berwirausaha justru sering dianggap sebagai penghasilan sampingan jika dibandingkan dengan bekerja sebagai karyawan dari perusahaan lain.

Akar masalah dari kewirausahaan mitra adalah manajemen keuangan dan penentuan nilai usaha yang masih belum mampu dilakukan oleh mitra dengan baik. Dalam kesempatan pengabdian yang dilakukan, mitra dibekali dengan semangat-semangat kewirausahaan serta kisah-kisah berwirausaha yang sukses.

\section{CAPAIAN HASIL KEGIATAN}

Pelaksanaan pengabdian yang telah dilaksanakan meliputi pembentukan kelompok, pengadaan kandang ternak, pemberian modal ternak, serta sosialisasi yang diperlukan mitra kelompok dalam menjalankan program pengabdian bersama dukungan tim. Pada tahapan kegiatan pengabdian, tim pengabdian telah berkoordinasi dengan mitra serta mengontol perkembangan yang terjadi pada kelompok mitra. Pada akhir pengabdian, tim akan melakukan diseminasi hasil pengabdian serta publikasi pada jurnal ilmiah terkait pengabdian yang telah dilakukan. Rencanarencana berikutnya dari tahap kegiatan pengabdian ini meliputi:

Tabel 1 Hasil Kegiatan

\begin{tabular}{|l|l|l|l|}
\hline Aspek & Kondisi Awal Mitra & Kondisi Akhir & Evaluasi \\
\hline $\begin{array}{l}\text { Pengembangan } \\
\text { Kelompok }\end{array}$ & $\begin{array}{l}\text { Dua kelompok mitra } \\
\text { masing-masing tiga } \\
\text { anggota }\end{array}$ & $\begin{array}{l}\text { Saat ini tiap kelompok } \\
\text { sudah memiliki lima } \\
\text { anggota dan jumlah } \\
\text { kelompok bertambah satu }\end{array}$ & Sangat Baik \\
\hline $\begin{array}{l}\text { Budidaya } \\
\text { Ternak }\end{array}$ & $\begin{array}{l}\text { 6 Ekor biri-biri dan 4 Ekor } \\
\text { kambing Jawa }\end{array}$ & $\begin{array}{l}\text { Kelompok memiliki 8 Ekor } \\
\text { Biri-Biri dan 5 Ekor } \\
\text { Kambing Jawa, serta hasil } \\
\text { anakan telah mulai bergilir }\end{array}$ & Sangat Baik \\
\hline $\begin{array}{l}\text { Perhitungan } \\
\text { harga pokok dan } \\
\text { keuangan }\end{array}$ & Tidak dilaksanakan & $\begin{array}{l}\text { 25\% dari seluruh anggota } \\
\text { mitra mulai menerapkan } \\
\text { aspek akuntansi dalam } \\
\text { kegiatan usaha serta } \\
\text { memisahkan keuangan } \\
\text { usaha dengan keluarga }\end{array}$ & Baik \\
\hline Kewirausahaan & $\begin{array}{l}\text { Semangat mitra masih } \\
\text { fluktuatif }\end{array}$ & $\begin{array}{l}\text { Mitra tetap komitmen } \\
\text { dalam mencapai }\end{array}$ & Sangat Baik \\
\hline
\end{tabular}


Prihatin. et.al. Peningkatan Ekonomi Masyarakat Desa Telun Kenas Melalui Optimisasi Manajemen Usaha Ternak Kelompok

\begin{tabular}{|l|l|l|l|}
\hline \hline & $\begin{array}{l}\text { pertumbuhan usaha yang } \\
\text { sustain }\end{array}$ & \\
\hline $\begin{array}{l}\text { Publikasi Hasil } \\
\text { Pengabdian }\end{array}$ & - & $\begin{array}{l}\text { Akan dilaksanakan } \\
\text { publikasi pada jurnal } \\
\text { LPPM USU }\end{array}$ & Belum Terlaksana \\
\hline $\begin{array}{l}\text { Video } \\
\text { Dokumentasi }\end{array}$ & - & $\begin{array}{l}\text { Publikasi kegiatan } \\
\text { pengabdian melalui } \\
\text { Youtube }\end{array}$ & $\begin{array}{l}\text { Dalam proses } \\
\text { editing, 1 minggu } \\
\text { sebelum unggah }\end{array}$ \\
\hline
\end{tabular}

\section{KESIMPULAN DAN SARAN}

Kegiatan pengabdian yang telah dilaksanakan pada masyarakat Desa Telin Kenas memberikan kesimpulan bahwa:

1. Wilayah Telun Kenas sangat potensial untuk budidaya ternak berdasarkan dukungan pakan ternak yang tersebar luas di kawasan tersebut. Masyarakat juga menyadari hal tersebut dan banyak yang memulai usaha beternak, namun terhenti di tengah jalan. Kegiatan pengabdian yang dilakukan memberikan solusi manajemen usaha yang sustainable. Sejauh ini mitra berhasil menyerap ipteks yang diberikan dengan baik dan kedepannya akan terus didampingi dan dikontrol agar tercapai target yang diharapkan.

2. Antusias masyarakat dengan program pengabdian dan bantuan dalam pemberdayaan masyarakat sangat disambut dengan baik oleh masyarakat setempat.

3. Manajemen kelompok sudah tercermin cukup baik dari mitra dan kelompoknya dengan membagi waktu antara pengelolaan ternak kelompok dengan tidak mengganggu waktu kerja bagi masing-masing anggota. Bila ada anggota yang berhalangan menjalankan tugas kelompok, anggota lain siap menggantikan agar tidak mengganggu jalannya kegiatan kelompok.

4. Penentuan harga jual yang layak masih menjadi dilema bagi mitra dan kelompoknya. Pembekalan yang dilakukan masih perlu dikembangkan dan dilatih agar mitra terbiasa dalam melakukan perhitungan harga pokok produksi serta harga jual yang layak dengan tepat. Sebagian mitra telah mengalami perubahan sikap dalam menangani keuangan namun masih belum optimal.

5. Masalah kewirausahaan bersumber dari kebutuhan rumah tangga. Kegiatan pengabdian ini memberikan solusi bagaimana memisahkan kehidupan rumah tangga dan usaha serta menjalankan keduanya dengan saling membantu.

Dengan mengacu pada kegiatan yang telah dilakukan serta temuan-temuan yang dihasilkan selama proses pengabdian, tim menyarankan hal-hal berikut:

1. Koherensi antara masyarakat, akademisi, serta pemerintah masih tetap dibutuhkan untuk mendorong pemberdayaan masyarakat setempat. Pemberian bantuan tidak akan berjalan dengan baik tanpa ada dukungan pendampingan kepada masyarakat

2. Masyarakat siap bekerjasama dengan akademisi dan pihak lain dalam upaya pembangunan kesejahteraan bersama. Kunci kepercayaan masyarakat pada penyelenggara kegiatan adalah bukti nyata dari kegiatan yang dilakukan. Ide-ide yang diberikan kepada masyarakat tanpa bentuk nyata yang diberikan tidak dianggap serius oleh masyarakat jika tidak disertai dengan dukungan nyata.

3. Potensi usaha ternak yang tinggi dapat dimaksimalkan dengan pemberdayaan usaha ternak kelompok. Dari kelompok binaan ini terlahir bibit-bibit budidaya ternak mandiri serta kelompok yang lebih besar dan pada akhirnya berdampak pada peningkatan pendapatan masyarakat setempat secara menyeluruh 


\section{UCAPAN TERIMA KASIH}

Peneliti mengucapkan terima kasih atas support dana dari BPPTN Universitas Sumatera Utara tahun 2018 dan seluruh tim LPPM USU sehingga pengabdian kepada masyarakat ini dapat berjalan.

\section{REFERENSI}

Kementerian Riset, Teknologi, dan Pendidikan Tinggi. (2016). Pendidikan Pancasila untuk Perguruan Tinggi. Jakarta: Direktorat Jendral Pembelajaran dan Kemahasiswaan

Merrill, D.N., dan Burrola, B.A. (2015). International education's role in Indonesia's "mental revolution": A path to prosperity in the global economy?, Strategic Review 5(1), Hal: 21-32

Robbins, S.P., dan Judge, T.A. (2013). Organizational Behaviour (15th Edition). New Jersey: Prentice Hall, Ebook Edition

Rohaeni, E.S. (2014). Analisis Potensi Wilayah untuk Pengembangan Usaha Ternak Sapi Potong di Kabupaten Tanah Laut, Kalimantan Selatan, Prosiding Seminar Nasional "Inovasi Teknologi Pertanian Spesifik Lokasi", Banjarbaru 6-7 Agustus 2014, Hal: 493-501

Stevenson, W. J. dan Chuong S.C. (2014). Manajemen Operasi: Perspektif Asia. Jakarta: Salemba Empat 